\title{
Development and Organoleptic Evaluation of Bakery Products and Extruded Snacks Prepared from Composite Flour
}

\author{
Manisha Pandit* and Navjot Kaur \\ Department of Food and Nutrition, Punjab Agricultural University, Ludhiana, India \\ *Corresponding author
}

K e y w o r d s
Composite flour,
Bakery products,
Nutritional, Anti-
nutritional factors,
Value added
Article Info
Accepted:
08 January 2020
Available Online:
10 February 2020

The present study is carried out to evaluate effective utilization of composite flour for development of bakery and extruded products. Biscuits, bread, doughnuts, cake and extruded snacks were prepared with blends of flours at various levels and were organoleptically evaluated using nine point hedonic rating scale for sensory parameters such as appearance, colour, texture, flavour and overall acceptability by semi-trained panel of judges. Wheat flour was used for control sample and three formulations prepared from blend of flours i.e. S1- (70\% WF: $10 \%$ SF: 17.5\% OF: $2.5 \%$ PF); S2-(70\% WF: 12\% SF: $14.5 \%$ OF: 3.5\% PF); S3-(70\% WF: $15 \%$ SF: $10.5 \%$ OF: $4.5 \%$ PF) showed significant and non- significant difference for development of value added products and evaluated on the basis of sensory attributes. Results revealed that among experimental samples the sensory evaluation of bakery foods the S1 sample was acceptable in biscuits, S2 sample in bread, doughnuts, extruded snacks and S3 was highly acceptable in cakes. It was concluded that incorporation of blends of these flours in value-added products can be alternative for refined flour in bakery products for future commercialization of products.

\section{Introduction}

Diet plays an important role in prevention of various metabolic diseases. Inadequate nutrition might lead to malnutrition, growth retardation, reduced work capacity and poor mental and social development. Owing to the increasing population, several people are getting malnourished and bound to poverty mainly in Asia and Africa. About 840 million people are unable to meet their daily energy requirements from their diets according to
Food and Agriculture Organisation. Approximately 95 percent of this number lives in the developing countries of Asia and Africa. In these countries, due to lack of sufficient and quality food about 40,000 people were dying and 800 million people suffer chronically from the consequences of poor nutrition and other millions are reported to have vitamin $\mathrm{A}$, iron and iodine deficiencies. There is a need to significantly increase protein quantity and overall quality of the diet to decrease protein malnutrition in 
the developing countries. High malnutrition rate has been associated with high bulk and low energy density foods. Food industry is facing the challenge of developing new products with the special health enhancing characteristics (Raihan and Saini, 2017). Bakery products are the integral part of meals in some countries. In India, it is not a staple food but generally eaten at the time of breakfast or hi tea and used for making bakery-based products. Bakery products are generally made from the flour, yeast, salt and water. Cereals and pulses have limiting amino acids - lysine and methionine. In order to offset the deficits of both amino-acids cereals are often combined with pulses to get high quality protein. Composite flours containing wheat and legumes have proven practical uses and are being utilized in many parts of the world to improve the nutritional and functional properties of flour. Composite flour was defined as a mixture of several flours obtained from roots, tubers, cereals and legumes with or without the addition of wheat flour (Shittu et al., 2007). According to Jisha et al., (2008) the use of composite flour can also boost country economy if its demand for bread and other bakery products are met by the locally grown products. This will reduce the import of wheat from other countries and thus will be economically beneficial. Supplementation of wheat flour with in expensive staples such as cereals and pulses help to improve the nutritional quality of wheat products. Supplementation of wheat flour with not more than 30 percent soy bean flour would greatly improve the quality as well as quantity of nutritional protein in bread. The composite flour technology plays a vital role to promote various high yielding local plant species which are underutilized and enhances the overall use of the domestic agriculture. Wheat (Triticum aestivum) is the main staple food of large sections of world population. It is the major food produce among all the cereal crops. Legumes are highly rich in protein and have low-glycemic index carbohydrates, essential micronutrients and fiber. One of them is soybean which is a cheap source of quality protein and is superior to all other plant foods because it has a good balance of all essential amino acid and contains a proper amount of methionine. Oats is considered as secondary crop that is derived from a weed of the primary cereal domesticates wheat and barley. It will help in lowering the blood cholesterol, glucose and insulin concentration because oats contain high total dietary fibre and $\beta$ glucan. Pumpkin is the most important vegetable grown in all over India. It belongs to the family Cucurbitaceae. Pumpkins are widely grown in tropical and subtropical countries. The pumpkin leaves are considered as underutilized part of plant, people generally discard leaves as such because they generally consume their vegetable part but not leafy part which is highly rich in all nutrients especially calcium, protein, iron, low in fat and highly rich in antioxidants which help in scavenging free radicals and overcome the risk of various diseases. The use of the blends of different flours from cereals, legumes, tubers and vegetables for production of different products boost the utility of local crops as raw materials and increase the nutritional quality of various food products. In the food industry, functional food development is an emerging as quite interesting and important field where multigrain-based products renewed interest to their nutritional composition (Ahmad et al., 2014) So, the composite flour could be considered as cheap alternative flour to wheat flour. The objective of the study was to conduct the sensory evaluation of value-added products developed by using composite flours.

\section{Materials and Methods}

The sample of wheat (HD-2967), soybean (SL-744), oats (OL-9) were procured from 
Department of Plant Breeding and Genetics and pumpkin leaves (Punjab samrat) were procured from Department of Vegetable Science, College of Agriculture, PAU, Ludhiana.

\section{Processing of wheat, soybean and oats}

Wheat, soybean and oat grains were thoroughly cleaned to remove dirt, dust, insect excreta feathers and admixture of other food grains. The clean graded grains were dried in the drier at $60^{\circ} \mathrm{C}$ for $7-8$ hours. The dried grains were grounded into fine flour. The flour samples obtained were kept in air tight containers before use.

\section{Preparation of pumpkin leaf powder}

The fresh leaves of pumpkin were washed in tap water to remove the foreign material and were dried in oven at $40^{\circ} \mathrm{C}$ for $4-6$ hours and having moisture content $7-8 \%$ were ground into powdered form in the electric grinder. The fine powder was kept in air tight container before use.

Preparation of different proportions of blends of composite flour

Composite flour based bakery products such as biscuits, bread and doughnuts was prepared by using wheat flour, oat flour, soy flour, pumpkin leaf powder in experimental samples in different ratios $\mathrm{S} 1-70 \%$ Wheat flour+ $10 \%$ soy flour $+17.5 \%$ oat flour $+2.5 \%$ pumpkin leaf powder, S2- 70\% Wheat flour $+12 \%$ soy flour $+14.5 \%$ oat flour $+3.5 \%$ pumpkin leaf powder, $\mathrm{S} 3-70 \%$ Wheat flour $+15 \%$ soy flour $+10.5 \%$ oat flour $+4.5 \%$ pumpkin leaf powder and wheat flour is used for control samples \{ Control(C) $-100 \%$ Wheat flour $\}$ in the Experiential Learning Unit, Department of Food and Nutrition, Punjab Agricultural University, Ludhiana. For each product one control samples and three experimental samples were developed by using composite flours at different levels. The value-added developed products were evaluated organoleptically and most acceptable products were also analyzed nutritionally

\section{Development of value-added bakery products using composite flours}

\section{Biscuits}

$50 \mathrm{~g}$ fat was rubbed on clean flat surface. Wheat flour (120g) was sifted with baking soda $(0.5 \mathrm{~g})$ and baking powder $(0.5 \mathrm{~g})$. Gradually refined sugar $(60 \mathrm{~g})$ was added to fat creamed till light and fluffy. Then sieved mixture of dry ingredients was added in the fat. A very smooth dough was prepared from the mixture using milk $(13 \mathrm{ml})$ containing dissolved ammonium bicarbonate $(0.5 \mathrm{~g})$. Dough was rolled in $14^{\text {th }}$ inch thick sheet and desired shape was cut using cutter and baked at $150^{\circ} \mathrm{C}$ for $10-15$ minutes.

\section{Doughnuts}

The yeast $(10 \mathrm{~g})$ and sugar $(5 \mathrm{~g})$ were added in luke warm milk $(50 \mathrm{ml})$. The mixture was left for 5-7 minutes for activation of yeast. All the dry ingredients (refined flour $-250 \mathrm{~g}$, salt-5g, milk powder-50g) were sieved and mixed well to make dough out of it with milk (100 $\mathrm{ml})$. Butter was added to the dough to make the consistency of dough sticky and knead well, placed in a dusted bowl for fermentation (one hour). After one-hour sheeting was done rolled by rolling pin and with the help doughnut cutter, the sheet was cut into desired shape and kept for final proofing for another one hour. After proofing the size was double, then doughnuts were deep fried in oil.

\section{Bread}

About $7.5 \mathrm{~g}$ fresh yeast was dissolved with refined sugar $(15 \mathrm{~g})$ in luke warm water for 
flying fermentation. The wheat flour $(250 \mathrm{~g})$ with salt (5g) was sieved properly. Water mixture was added in dry ingredients and kneaded into dough by stretching it. Oil (100ml) was added to dough to stop the gluten formation. Then dough was kept for proofing at $43-50^{\circ} \mathrm{C}$ for 20 minutes until its volume doubled. The dough was divided into two half and rolled into a ball and placed in greased pan covered with wet cloth after proofing and let to rise until doubled for 45 minutes. Bread loaf was baked $200^{\circ} \mathrm{C}$ for 30 minutes and cooled on rack. Bread loaf was cut with bread slicer cutter.

\section{Cake}

Fat (100g) and refined sugar (50g) were creamed together till light and fluffy. Wheat flour (100g) was sifted with baking soda $(0.5 \mathrm{~g})$, baking powder $(0.5 \mathrm{~g})$ and milk powder $(50 \mathrm{~g})$ twice. Then sieved mixture of dry ingredients were added in the creamy fat and mixed well using cut-fold method. Milk $(150 \mathrm{ml})$ was added and mixed well until desired consistency was achieved. This creamed mixture was poured into mold which was greased and dusted with oil. The mixture was baked at $190{ }^{\circ} \mathrm{C}$ for 20 minutes and was left to cool on a cooling rack after baking.

\section{Extruded snacks}

The ready to eat snacks were made by using co-rotating intermeshing twin screw extruder (Clextral, Firminy and France). Wheat flour $(100 \mathrm{~g})$ and salt $(2 \mathrm{~g})$ were sifted twice and extruded snacks were prepared using extruder machine. Wheat flour (100g) was used for control samples. For experimental samples of extruded snacks viz. S1, S2 and S3, $30 \mathrm{~g}$ of wheat flour was replaced by 10,12 and $15 \mathrm{~g}$ of soybean flour; $17.5,14.5$ and $10.5 \mathrm{~g}$ of oats flour and 2.5, 3.5 and $4.5 \mathrm{~g}$ of pumpkin leaf powder, respectively.

\section{Sensory evaluation}

Composite flour based value-added bakery products were organoleptically evaluated by a panel of semi-trained 10 judges using 9-point hedonic rating scale. The judges were served with the baked products constituting of 3 experimental sample (S) and the control sample (C) prepared by standardized method without substitution whereas the experimental sample were prepared with substitution with wheat flour with composite flours at the ratios of S1- $70 \%$ Wheat flour+ $10 \%$ soy flour + $17.5 \%$ oat flour $+2.5 \%$ pumpkin leaf powder, S2- $70 \%$ Wheat flour $+12 \%$ soy flour $+14.5 \%$ oat flour $+3.5 \%$ pumpkin leaf powder, S3$70 \%$ Wheat flour $+15 \%$ soy flour $+10.5 \%$ oat flour $+4.5 \%$ pumpkin leaf powder. The panelist was asked to score the samples for all the sensory parameters like appearance, colour, taste, flavour, texture and overall acceptability by using 9-point hedonic (Rangana, 2002). The degree to which a developed product was liked, hence expressed with scores as: liked extremely-9, liked very much-8, liked moderately-7, liked slightly-6, neither liked nor disliked-5, disliked slightly4 , disliked moderately-3, disliked very much2 and disliked extremely- 1 .

\section{Statistical analysis}

The collected data was analyzed with the help of statistical tools such as mean and standard deviation. To analyse the test the significance difference between control and experimental samples of value-added products, Kruskal Wallis, Duncan test and ANOVA using SPSS 16.0 software.

\section{Results and Discussion}

Sensory evaluation of value-added developed bakery products

The sensory evaluation of composite flour based value added bakery products is 
prepared in Table 1. Four samples of each product were prepared by using wheat flour and composite flour was prepared from various combinations of flours. The samples constituted of one control sample which was developed from whole wheat flour while the other three experimental samples were developed with composite flour at S1$70 \%$ wheat flour $+10 \%$ soy flour $+17.5 \%$ oat flour $+2.5 \%$ pumpkin leaf powder, S2$70 \%$ wheat flour $+12 \%$ soy flour $+14.5 \%$ oat flour $+3.5 \%$ pumpkin leaf powder, S3$70 \%$ wheat flour $+15 \%$ soy flour $+10.5 \%$ oat flour $+4.5 \%$ pumpkin leaf powder.

\section{Biscuits}

The results showed significantly highest scores of biscuits for all sensory parameters were obtained by control (C) sample ranging from 7.6-8.0 with an overall acceptability scores of 7.86 and fell in the category of liked very much, followed by S1, S2 and S3 with an overall-acceptability scores of 7.80, 7.76 and 6.96 respectively. A non-significant difference was found in appearance and texture of control sample when compared with the S1, S2 and S3. A significant difference was found between control and S3 for taste, flavour and overall acceptability. Among the experimental samples which were developed using composite flour, S1 scored highest with respect to all parameters i.e. appearance, color, texture, taste, flavour i.e. 8.0, 8.0 7.3, 7.8 and 7.7. The highest and similar scores of appearance and color was found to be 8.0 for control and S1. With respect of flavour, color, texture and overall acceptability of S1 and S2 were found to be non-significant among each other as well as with control sample. The overall acceptability was found to be higher in control as compared to all experimental samples S1, S2 and S3. Rana (2015) developed biscuit using blanched pearl millet, sorghum, germinated mung bean and marwa leaves powder in the ratio of 55:20:20:5 and were found to be organoleptically acceptable. Sikandra and Boora (2009) reported that an incorporation of 40:30:30 of composite flour (sorghum, chickpea and wheat flours) in biscuit were liked moderately and more acceptable in terms of all sensory parameters. Haribhai (2016) reported that sensory parameters among all the treatment of biscuit differed significantly. Incorporation of Ragi flour (3): Soybean flour (2): Oats flour (2): Jowar flour (2): Maize flour (1) in the proportion was found to be organoleptically acceptable in biscuit.

\section{Doughnuts}

The results revealed that the control sample of doughnut was given scores ranging from 8.4 to 8.6 for different sensory attributes. Among the experimental samples which were developed using composite flour, S2 scored highest with respect of all the parameters such as appearance, color (8.0), texture (7.9), taste (7.7) and flavour (7.8) with an overall acceptability to be 7.88 and being liked very much. A non-significant difference was observed in appearance, color and texture of control sample when compared with $\mathrm{S} 1$ and S2 whereas significant difference was found in taste, flavour and overall acceptability for control and S3. However, in this case the scores regarding all sensory parameters were lower in experimental sample as compared to those of control. The overall acceptability was found to be higher in control as compared to the experimental sample S1, S2 and S3. Incorporation of soy flour in composite flour based doughnuts absorb low amount of fat during frying. This is because of denaturation of protein on the surface of doughnuts which create a barrier to absorption of fat and the fat is prevented from penetrating into the interior at the stage of frying (Endres, 2001). Kaur and Kaur (2019) reported that 10 percent incorporation of soybean variety (SL 958) in donuts was found to be highly acceptable (8.00) and no significant difference was found 
in both varieties of soybean (SL 525) and (SL 744).

\section{Bread}

The sensory evaluation of composite flour based bread is depicted in Table 2. The mean scores of breads statistically revealed that all experimental samples showed non-significant difference $(p>0.05)$ in respect of all sensory parameters like appearance color, texture, flavour and over acceptability whereas nonsignificant difference was observed in texture of S3 as compared to control sample i.e. 7.7 and 8.5 respectively. The highest score of overall acceptability was recorded in S2. i.e. 8.12 followed by control sample (8.02). The mean score for overall acceptability was found to be lower for $\mathrm{S} 3$ i.e. 7.76. The overall acceptability was found to be higher in S2 as compared to the control sample, S1 and S3. No significant difference was observed for control and experimental samples in respect of appearance, color, flavour, taste and overall acceptability ranged from 8.0-8.4, 7.9-8.4, 7.6-7.9 and 7.76-8.02. However, S3 was least preferable and being liked slightly with respect of other experimental samples. Sankararao et al., (2016) developed bread using 15 percent soybean, ragi and flax seed flour and were found to organoleptically acceptable as compared control sample of bread. Dankwa et al., (2016) reported that 10 percent incorporation of root tuber in bread was found to be organoleptically acceptable (8.4) and fell in the category of liked very much. Ayele et al., (2017) developed bread using wheat, cassava and soybean in the ratio of (49:29:22) and was observed to be more acceptable.

\section{Cake}

The sensory evaluation of composite flour based value added cake is presented in Table 2 . The result showed that significantly highest scores of cake for all sensory parameters were obtained by experimental sample (S3) sample with respect to all the parameters i.e. appearance, color, texture, taste, flavour i.e. 8.5, 8.3, 8.1, 8.2 and 8.3 ranging from 8.1-8.5 with an overall acceptability scores of 8.28 and fell in the category of liked very much, followed by control (C), S1 and S2 with an overall-acceptability scores of $8.16,8.16$ and 7.98 respectively. A non-significant difference was found in all sensory attributes for control and experimental samples, except color in S1 and S3 sample. The mean score for overall acceptability was found to be slightly lower in S2. Similar scores for taste and flavour was observed by S1 and S2 i.e 7.9 while with respect to appearance and taste $\mathrm{S} 3$ and control were found to be similar i.e. 8.5 and 8.2. A highly significant difference $(p \leq 0.05)$ was observed in the sensory scores of control and S2 in respect of color i.e. 8.6 and 7.9. With an increase level of blends of flour in the cake, the overall acceptability of cake was increased. The cake prepared from S3 combination scored slightly higher than cake prepared from S1 and S2 combination. Chhabra (2006) reported that 10 percent incorporation of bael powder was found to be organoleptically acceptable (7.14) and fell in category of like moderately as compared to control sample. Rana (2015) developed cake using blanched pearl millet, sorghum, germinated mung bean, and marwa leaves powder in the ratio of 55:20:20:5 and were found to be organoleptically more acceptable.

\section{Extruded snacks}

The mean scores of acceptability of extruded snacks by semi trained panel of judges using nine-point hedonic rating scale is depicted in Table 3. The results showed that mean scores of extruded snacks were found to be nonsignificant in control and S2 sample based on the parameters such as appearance, color, texture, flavour and overall acceptability Among the experimental samples which were developed using composite flour, S2 samples 
scored highest with respect of all the parameters such as appearance, color, texture, taste and flavour i.e. 7.9, 8.0, 7.9, 8.0 and 8.1 with an overall acceptability scores of 7.98 and fell in category of being liked very much followed by control (C) with an overall acceptability score of 7.90. The S3 sample was least preferable with an overall acceptability score 6.32. This was mainly due to increased incorporation of pumpkin leaf powder (3-5 percent) that gradually decreased the acceptability level of snacks and bitterness was increased in the experimental sample of extruded snacks. The overall acceptability was found to be higher in S2 experimental product as compared to the control sample, $\mathrm{S} 1$ and S3. However, a highly significant $(p \leq 0.05)$ difference was observed in the mean scores of controls for appearance, color, texture, taste and overall acceptability when compared with S1 and S3. Deshpande and Poshadari (2011) reported that the ratio of 60:20:10: 05:05 of foxtail millet, channa, cowpea, rice and amaranth powder prepared extruded product significantly found to have better texture, flavour, color, appearance and overall acceptability. Kumar (2013) reported that an incorporation of up to $20 \%$ cowpea flour in the maize oat composite mixes in prepared RTE extruded products was organoleptically more acceptable and 50\% incorporation of cow pea flour in composite mix RTE snacks fell in the category of liked moderately. Incorporation of up to 20 percent of yam, beetroot and sweet potato in extruded product was organoleptically acceptable and also revealed that no statistically significant difference was found between control and extruded snacks. (Reddy et al., 2014).

Table.1 Organoleptic scores of biscuits and doughnut products using composite flour (mean \pm SD)

\begin{tabular}{|l|c|c|c|c|c|c|}
\hline Levels & Appearance & Colour & Texture & Taste & Flavour & Overall Acceptability \\
\hline Control & $8.0 \pm 0.47^{\mathrm{a}}$ & $8.0 \pm 0.47^{\mathrm{a}}$ & $7.6 \pm 0.69^{\mathrm{a}}$ & $7.9 \pm 0.73^{\mathrm{a}}$ & $7.8 \pm 0.78^{\mathrm{a}}$ & $7.86 \pm 0.56^{\mathrm{a}}$ \\
\hline S1 & $8.0 \pm 0.66^{\mathrm{a}}$ & $8.0 \pm 0.66^{\mathrm{a}}$ & $7.3 \pm 0.94^{\mathrm{a}}$ & $7.8 \pm 0.78^{\mathrm{a}}$ & $7.7 \pm 0.82^{\mathrm{a}}$ & $7.8 \pm 0.68^{\mathrm{a}}$ \\
\hline S2 & $7.8 \pm 0.78^{\mathrm{a}}$ & $7.7 \pm 0.82^{\mathrm{ab}}$ & $7.9 \pm 0.73^{\mathrm{a}}$ & $7.7 \pm 0.94^{\mathrm{a}}$ & $7.7 \pm 0.67^{\mathrm{a}}$ & $7.76 \pm 0.69^{\mathrm{a}}$ \\
\hline S3 & $7.4 \pm 0.51^{\mathrm{a}}$ & $7.3 \pm 0.82^{\mathrm{a}}$ & $7.2 \pm 0.78^{\mathrm{a}}$ & $6.3 \pm 0.94^{\mathrm{b}}$ & $6.5 \pm 0.94^{\mathrm{b}}$ & $6.96 \pm 0.57^{\mathrm{b}}$ \\
\hline$\chi^{\mathbf{2}}$ & $6.01^{N S}$ & $6.47^{N S}$ & $3.55^{N S}$ & $13.47^{* *}$ & $1.85^{N S}$ & $10.85^{N S}$ \\
\hline Control & $8.5 \pm 0.52^{\mathrm{a}}$ & $8.6 \pm 0.51^{\mathrm{a}}$ & $8.4 \pm 0.69^{\mathrm{a}}$ & $8.5 \pm 0.52^{\mathrm{a}}$ & $8.4 \pm 0.51^{\mathrm{a}}$ & $8.46 \pm 0.49^{\mathrm{a}}$ \\
\hline S1 & $7.9 \pm 0.73^{\mathrm{a}}$ & $7.9 \pm 0.87^{\mathrm{a}}$ & $7.7 \pm 0.82^{\mathrm{a}}$ & $7.4 \pm 0.51^{\mathrm{b}}$ & $7.4 \pm 0.51^{\mathrm{b}}$ & $7.66 \pm 0.61^{\mathrm{b}}$ \\
\hline S2 & $8.0 \pm 0.66^{\mathrm{a}}$ & $8.0 \pm 0.81^{\mathrm{a}}$ & $7.9 \pm 0.56^{\mathrm{a}}$ & $7.7 \pm 0.82^{\mathrm{b}}$ & $7.8 \pm 0.78^{\mathrm{ab}}$ & $7.88 \pm 0.52^{\mathrm{ab}}$ \\
\hline S3 & $6.7 \pm 1.15^{\mathrm{b}}$ & $6.5 \pm 1.08^{\mathrm{b}}$ & $6.3 \pm 0.94^{\mathrm{b}}$ & $6.3 \pm 0.82^{\mathrm{c}}$ & $6.3 \pm 0.94^{\mathrm{c}}$ & $6.42 \pm 0.83^{\mathrm{c}}$ \\
\hline$\chi^{\mathbf{2}}$ & $15.24^{* *}$ & $17.10^{* *}$ & $19.19^{* *}$ & $22.73^{* *}$ & $21.43^{* *}$ & $22.60^{* *}$ \\
\hline
\end{tabular}

* Duncan test significant at 5\% level of significance

The mean values with different notation ( $a, b, c$ and $d)$ implies they are significantly different $(\mathrm{p}<0.05)$

**Significant at $1 \%$ level of significance $(\mathrm{p}<0.01)$

* Significant at $5 \%$ level of significance $(\mathrm{p}<0.05)$

NS - Non significant using Kruskal wallis test.

Control(C) $-100 \%$ Wheat flour

S1 $-70 \%$ Wheat flour $+10 \%$ soy flour $+17.5 \%$ oat flour $+2.5 \%$ pumpkin leaf powder

S2 $-70 \%$ Wheat flour $+12 \%$ soy flour $+14.5 \%$ oat flour $+3.5 \%$ pumpkin leaf powder

$\mathrm{S} 3-70 \%$ Wheat flour $+15 \%$ soy flour $+10.5 \%$ oat flour $+4.5 \%$ pumpkin leaf powder 
Table.2 Organoleptic scores of bread and cake products using composite flour (mean \pm SD)

\begin{tabular}{|l|l|l|l|l|l|l|}
\hline Levels & Appearance & Colour & Texture & Taste & Flavour & $\begin{array}{l}\text { Overall } \\
\text { Acceptability }\end{array}$ \\
\hline \multicolumn{7}{|c|}{ Bread } \\
\hline Control & $8.4 \pm 0.51^{\mathrm{a}}$ & $8.4 \pm 0.51^{\mathrm{a}}$ & $8.5 \pm 0.70^{\mathrm{a}}$ & $7.9 \pm 0.87^{\mathrm{a}}$ & $7.9 \pm 0.87^{\mathrm{a}}$ & $8.02 \pm 0.55^{\mathrm{a}}$ \\
\hline S1 & $8.3 \pm 0.48^{\mathrm{a}}$ & $7.8 \pm 0.78^{\mathrm{a}}$ & $7.9 \pm 0.73^{\mathrm{ab}}$ & $7.8 \pm 0.78^{\mathrm{a}}$ & $7.8 \pm 0.78^{\mathrm{a}}$ & $7.92 \pm 0.50^{\mathrm{a}}$ \\
\hline S2 & $8.2 \pm 0.63^{\mathrm{a}}$ & $8.0 \pm 0.66^{\mathrm{a}}$ & $8.2 \pm 0.78^{\mathrm{ab}}$ & $8.3 \pm 0.67^{\mathrm{a}}$ & $7.9 \pm 0.73^{\mathrm{a}}$ & $8.12 \pm 0.59^{\mathrm{a}}$ \\
\hline S3 & $8.0 \pm 0.66^{\mathrm{a}}$ & $7.9 \pm 0.73^{\mathrm{a}}$ & $7.7 \pm 0.67^{\mathrm{b}}$ & $7.6 \pm 0.69^{\mathrm{a}}$ & $7.6 \pm 0.69^{\mathrm{a}}$ & $7.76 \pm 0.57^{\mathrm{a}}$ \\
\hline $\boldsymbol{\chi}^{\mathbf{2}}$ & $2.26^{\mathrm{NS}}$ & $4.22^{N S}$ & $6.42^{N S}$ & $4.34^{N S}$ & $1.002^{N S}$ & $4.45^{N S}$ \\
\hline & & & Cake $^{\mathrm{NS}}$ & & & \\
\hline Control & $8.5 \pm 0.52^{\mathrm{a}}$ & $8.6 \pm 0.51^{\mathrm{a}}$ & $8.5 \pm 0.52^{\mathrm{a}}$ & $8.2 \pm 0.42^{\mathrm{a}}$ & $8.5 \pm 0.52^{\mathrm{a}}$ & $8.16 \pm 0.38^{\mathrm{a}}$ \\
\hline S1 & $8.4 \pm 0.51^{\mathrm{a}}$ & $8.4 \pm 0.51^{\mathrm{ab}}$ & $8.2 \pm 0.78^{\mathrm{a}}$ & $7.9 \pm 0.73^{\mathrm{a}}$ & $7.9 \pm 0.73^{\mathrm{a}}$ & $8.16 \pm 0.54^{\mathrm{a}}$ \\
\hline S2 & $8.2 \pm 0.63^{\mathrm{a}}$ & $7.9 \pm 0.56^{\mathrm{b}}$ & $8.0 \pm 0.47^{\mathrm{a}}$ & $7.9 \pm 0.99^{\mathrm{a}}$ & $7.9 \pm 0.99^{\mathrm{a}}$ & $7.98 \pm 0.60^{\mathrm{a}}$ \\
\hline S3 & $8.5 \pm 0.70^{\mathrm{a}}$ & $8.3 \pm 0.67^{\mathrm{ab}}$ & $8.1 \pm 0.73^{\mathrm{a}}$ & $8.2 \pm 0.78^{\mathrm{a}}$ & $8.3 \pm 0.67^{\mathrm{a}}$ & $8.28 \pm 0.50^{\mathrm{a}}$ \\
\hline $\boldsymbol{\chi}^{\mathbf{2}}$ & $1.79^{\mathrm{NS}}$ & $6.76^{\mathrm{NS}}$ & $3.45^{\mathrm{NS}}$ & $1.34^{N S}$ & $3.60^{N S}$ & $3.83^{N S}$ \\
\hline
\end{tabular}

* Duncan test significant at $5 \%$ level of significance

The mean values with different notation $(a, b, c$ and $d)$ implies they are significantly different $(p<0.05)$

$* *$ Significant at $1 \%$ level of significance $(\mathrm{p}<0.01)$

* Significant at $5 \%$ level of significance $(\mathrm{p}<0.05)$

NS - Non significant using Kruskal wallis test.

Control(C) $-100 \%$ Wheat flour

S1- $70 \%$ Wheat flour $+10 \%$ soy flour $+17.5 \%$ oat flour $+2.5 \%$ pumpkin leaf powder

S2- $70 \%$ Wheat flour $+12 \%$ soy flour $+14.5 \%$ oat flour $+3.5 \%$ pumpkin leaf powder

Table.3 Organoleptic scores of value-added extruded snacks using composite flour (mean \pm SD)

\begin{tabular}{|c|c|l|l|l|l|c|}
\hline Levels & Appearance & Colour & Texture & Taste & Flavour & $\begin{array}{l}\text { Overall } \\
\text { Acceptability }\end{array}$ \\
\hline \multicolumn{7}{|c|}{ Extruded Product (Snacks) } \\
\hline Control & $8.0 \pm 0.66^{\mathrm{a}}$ & $8.0 \pm 0.66^{\mathrm{a}}$ & $7.8 \pm 0.63^{\mathrm{a}}$ & $7.9 \pm 0.56^{\mathrm{a}}$ & $7.8 \pm 0.63^{\mathrm{ab}}$ & $7.9 \pm 0.53^{\mathrm{a}}$ \\
\hline S1 & $7.3 \pm 0.48^{\mathrm{b}}$ & $7.4 \pm 0.51^{\mathrm{a}}$ & $7.4 \pm 0.69^{\mathrm{a}}$ & $7.3 \pm 0.67^{\mathrm{b}}$ & $7.3 \pm 0.67^{\mathrm{b}}$ & $7.34 \pm 0.41^{\mathrm{b}}$ \\
\hline S2 & $7.9 \pm 0.73^{\mathrm{a}}$ & $8.0 \pm 0.66^{\mathrm{a}}$ & $7.9 \pm 0.56^{\mathrm{a}}$ & $8.0 \pm 0.47^{\mathrm{a}}$ & $8.1 \pm 0.73^{\mathrm{a}}$ & $7.98 \pm 0.50^{\mathrm{a}}$ \\
\hline S3 & $6.2 \pm 0.63^{\mathrm{c}}$ & $6.4 \pm 0.82^{\mathrm{b}}$ & $6.3 \pm 0.82^{\mathrm{b}}$ & $6.4 \pm 0.69^{\mathrm{c}}$ & $6.3 \pm 0.82^{\mathrm{c}}$ & $6.32 \pm 0.62^{\mathrm{c}}$ \\
\hline$\chi^{\mathbf{2}}$ & $22.71^{*}$ & $18.67^{*} *$ & $17.32^{*} *$ & $22.09^{*}$ & $19.40^{* *}$ & $23.91^{*}$ \\
\hline
\end{tabular}

* Duncan test significant at $5 \%$ level of significance

The mean values with different notation $(a, b, c$ and $d)$ implies they are significantly different $(p<0.05)$

**Significant at $1 \%$ level of significance $(\mathrm{p}<0.01)$

* Significant at $5 \%$ level of significance $(\mathrm{p}<0.05)$

NS - Non significant using Kruskal wallis test.

Control(C) $-100 \%$ Wheat flour

S1- $70 \%$ Wheat flour $+12 \%$ soy flour $+17.5 \%$ oat flour $+2.5 \%$ pumpkin leaf powder

S2- $70 \%$ Wheat flour $+12 \%$ soy flour $+14.5 \%$ oat flour $+3.5 \%$ pumpkin leaf powder

S3-70\% Wheat flour $+15 \%$ soy flour $+10.5 \%$ oat flour $+4.5 \%$ pumpkin leaf powder 
Table.4 Acceptable level of developed products using composite flour

\begin{tabular}{|l|l|}
\hline \multicolumn{1}{|c|}{ Value added products } & \multicolumn{1}{c|}{ Acceptable level (percentage) } \\
\hline Biscuits & $\begin{array}{r}\text { Bakery products } \\
\text { S1-70\%Wheat flour }+10 \% \text { soy flour }+17.5 \% \\
\text { oat flour }+2.5 \% \text { pumpkin leaf powder }\end{array}$ \\
\hline Doughnut & S2-70\%Wheat flour $+12 \%$ soy flour + \\
Bread & $14.5 \%$ oat flour $+3.5 \%$ pumpkin leaf powder \\
\hline Cake & S3- 70\%Wheat flour $+15 \%$ soy flour + \\
& $10.5 \%$ oat flour $+4.5 \%$ pumpkin leaf powder \\
\hline Extruded snacks & Extruded products \\
\hline & S2- 70\%Wheat flour $+12 \%$ soy flour + \\
& $14.5 \%$ oat flour $+3.5 \%$ pumpkin leaf powder \\
\hline
\end{tabular}

Acceptable level of the value-added products

All the products developed by using composite flour were found to be acceptable at different levels in the different products has been presented in Table 4 . In bakery products such as biscuit was found to be acceptable in S1 ratio's and doughnut and bread showed highly acceptable values at S2 ratio's of composite flour whereas cake was observed to be most acceptable values at S3 ratio's of composite flour were liked very much with an overall acceptability ranging from 7.8 to 8.40 . In extruded products, the snacks were found to be most acceptable values at S2 ratio's of composite flour with an overall acceptability scores to be 7.98. It was observed that overall acceptability of cake was increased by increasing the ratio of soybean flour, oats flour and pumpkin leaf powder. It was not decreased.

In conclusion, the composite flour technology for wheat supplementation with protein rich component like soybean is a good technique to overcome the malnutrition and various degenerative diseases. Value added products developed from composite flour (wheat, soybean, oats and pumpkin leaf powder) were acceptable at all three proportion of flours. In value added products, the highest mean scores of 7.80 for all sensory parameters was obtained among experimental samples S1 of biscuits. For bread, doughnuts and extruded snacks obtained highest scored with an overall acceptability i.e. 7.88, 8.12 and 7.98 respectively of experimental sample (S2) of developed products. Cake prepared from blends of flours scored highest in experimental sample (S3) received with an overall acceptability 8.28. On the basis of results, it may be concluded that in order to combat malnutrition and various degenerative diseases such as cardiovascular diseases, PEM, obesity through healthy diet and consumption of value-added products developed from blends of flours could be beneficial for future industrial commercialization. Hence, the composite flour could be considered as cheap alternative flour to refined wheat flour and can be utilized in various food industry.

\section{References}

Ahmad, A., Hayat, I., Arif, S., Masud, T., Khalid, N., and Ahmed, A., 2014. Mechanisms involved in the therapeutic effects of soybean (Glycine Max). International Journal Food Properties 17, 1332-54.

Ayele, L., Majumdar, S., D., and Ravi, U., 2017. Mango (Mangifera indica L.) 
kernel flour as a potential ingredient in the development of composite flour bread. Indian Journal Natural Products Resources 5, 75-82.

Chhabra., 2006. Physico-chemical and functional properties of jackfruit seed Flour and quality enrichment of chapaties using Composite Flour. M Sc. Thesis, Department of Food Technology and Rural Industries, Bangladesh Agricultural University Mymensingh.

Dankwa, S., Khalid, N., Bibi, N., and Bibi, A., 2016. Effect of substitution of wheat with maize on technological and organoleptic properties of chapatis Asian Journal of Agricultural Rural Development 3, 449.

Deshpande, H., W., and Poshadri, A., 2011. Physical and sensory characteristics of extruded snacks prepared from Foxtail millet based composite flours. International Food Research Journal 18,751-6.

Endres, J., 2001. Soy flour products in baking. Dissertation in Ph.D. Rechnical foods Consultant.

Haribhai, P., D., 2016. Development of nutrient rich biscuits from blends of dairy and plant ingredients. Ph.D. Dissertation, Anand Agricultural University, Anand, India.

Jisha, S., Padmaja, G., Moorthy, S., N., and Rajeshkumar, K., 2008. Pre-treatment effect on the nutritional and functional properties of selected cassava-based composite flours. Innovation Food Science and Emerging Technologies 9:587-92.

Kaur, H., and Kaur, N., 2019. Development and sensory evaluation of value added bakery products developed from germinated soybean (Glycine max) varieties. Journal of Applied Natural
Science 11, 211-16.

Kumar, S., 2013. Processing and utilization of cereals and underutilized pulses for development of value added ready to eat extruded snacks. MSc. Thesis, Centre of Food Science and Technology College of Basic Sciences and Humanities, CCS Haryana Agricultural University Haryana.

Raihan, M., and Saini, C., S., 2017. Evaluation of various properties of composite flour from oats, sorghum, amaranth and wheat flour and production of cookies. International Food Research Journal 24, 2278-84.

Rana., 2015. Nutritional evaluation and acceptability of value added products based on composite flour (pearl milletsorghum-mung bean-marwa) Ph.D. Dissertation, CCS Haryana Agricultural University, Hissar, India.

Rangana, S., 2002. Handbook of analysis and quality control for fruits and vegetable products. Tata Mcgraw -Hill Publishing Company Limited, New Delhi.

Reddy, M., K., Kuna, A., Devi, N., L., Krishnaiah, N., Kaur, C., and Nagamalleswari, $\quad$ Y., 2014. Development of extruded Ready-To-Eat (RTE) snacks using corn, black gram, roots and tuber flour blends. Journal of Food Science Technology 51, 1929-37.

Sankararao, S., Verma, A., and Bala, N., 2016. Sensory and nutritional evaluation of unleavened flat bread prepared by multigrain flour mixture. Journal of Applied Natural Science 8, 1168-71.

Sikandra., and Boora, P., 2009. Nutritional evaluation of sorghum and chickpea incorporated value-added products Journal of Dairying Foods Humanity Science 28,181-5. 


\section{How to cite this article:}

Manisha Pandit and Navjot Kaur. 2020. Development and Organoleptic Evaluation of Bakery Products and Extruded Snacks Prepared from Composite Flour. Int.J.Curr.Microbiol.App.Sci. 9(02): 1680-1690. doi: https://doi.org/10.20546/ijcmas.2020.902.194 